\title{
Effects of water deprivation on atrial natriuretic peptide secretion and density of binding sites in adrenal glands and kidneys of maternal and fetal rats in late gestation
}

\author{
S Deloof, C De Seze, V Montel and A Chatelain \\ Laboratoire de Neuroendocrinologie du Développement (JE 234), Université des Sciences et Technologies de Lille, Bâtiment SN4, F-59655 Villeneuve \\ d'Ascq cedex, France \\ (Correspondence should be addressed to A Chatelain)
}

\begin{abstract}
The effects of water deprivation for 3 days were studied in pregnant rats and their fetuses on day 21 of gestation. Maternal water deprivation induced a significant decrease of the body weight in both maternal and fetal rats. This weight loss was accompanied by significant increases in plasma osmolality and haematocrit in both maternal and fetal rats. Similarly, dehydration significantly decreased plasma atrial natriuretic peptide (ANP) concentrations and increased plasma aldosterone concentrations in maternal and fetal rats. Water-deprived maternal rats presented a significant increase in total ANP receptor density in isolated renal glomeruli and adrenal zona glomerulosa membranes. This increase was due to a significant increase in ANPC receptor density in both renal glomeruli and adrenal zona glomerulosa. The densities of total ANP, ANPB and ANPc receptors in fetal kidneys and adrenal glands were not affected by maternal dehydration. These results suggest that the dehydrated maternal rat is able to up-regulate the number of its ANP receptors in its kidneys and adrenal glands, in response to a decrease in plasma ANP concentrations. In contrast, the fetal rat does not seem to be able to regulate its own ANP receptors in response to maternal dehydration, in spite of a decrease in plasma ANP concentrations.
\end{abstract}

European Journal of Endocrinology 141 160-168

\section{Introduction}

Rat pregnancy is characterized by a marked expansion of plasma volume and a retention of sodium (1). This implies that several hormonal factors, including arginine vasopressin (AVP), renin, angiotensin II, aldosterone and atrial natriuretic peptide (ANP), might be involved in the gestational volume expansion and sodium accumulation. Among these factors, ANP could play an important part. Indeed, ANP is a cardiac hormone that is stored in atrial secretory granules (2) and released into blood circulation in response to atrial distension (3). ANP stimulates natriuresis and diuresis by enhancing glomerular filtration rate and excretion of sodium and water (4) and inhibiting the secretion of aldosterone induced by angiotensin II (5), renin (6) and AVP (7). The biological activity of ANP is mediated through specific receptors, mainly located in renal glomeruli and adrenal zona glomerulosa of the adult rat (8).

In the fetal rat at term, immunoreactive plasma concentrations of ANP are higher than the maternal concentrations and increase in response to volume expansion $(9,10)$. Autoradiographic studies have shown the presence of ANP receptors in the kidney and the adrenal gland on day 16 of gestation (11). Alterations of water intake were performed in the adult rat in order to study the role of ANP in the regulation of body water. All the experiments have shown that water deprivation decreases plasma ANP concentrations (12-16) and increases the total number of ANP receptors in the kidney and the adrenal gland $(13-15,17)$.

In maternal and fetal rats, there is no information about the effects of water deprivation on the regulation of ANP secretion and receptor density. The aim of the present study was to evaluate the effects of 3-day water deprivation on plasma ANP and aldosterone concentrations of maternal and fetal rats in late gestation. In addition, in those experimental rats, the density and affinity of the different classes of ANP receptors were determined in adrenal glands and kidneys.

\section{Materials and methods}

\section{Animals}

Experiments were performed on Wistar rats bred in the laboratory. They were housed in a light-controlled room 
(light period 0700 to 1900 h). Females were mated with a male for 1 night. The following day was taken as day 0 of pregnancy if spermatozoa were found in vaginal smears. Pregnant females were divided into two groups: control group and dehydrated group. In the control group, the females had free access to tap water and standard rat chow. In the dehydrated group, the females were deprived of drinking water for 3 days from day 18 of gestation, but had free access to standard rat chow. All females were killed on day 21 of gestation by decapitation and truncal blood was collected between 0800 and $1000 \mathrm{~h}$. Their fetuses were rapidly delivered by caesarean section and bled at the trunk level in less than $4 \mathrm{~min}$ in order to avoid fetal stress.

\section{Blood collection}

Blood samples from fetal and pregnant females were collected in chilled plastic tubes containing 5\% EDTA $(20 \mu \mathrm{l} / 1 \mathrm{ml}$ blood $)$ and aprotinin $(500 \mathrm{U} / 1 \mathrm{ml}$ blood $)$. The blood samples were centrifuged at $5000 \mathrm{~g}$ for $10 \mathrm{~min}$ at $4^{\circ} \mathrm{C}$ and plasma samples were stored at $-80^{\circ} \mathrm{C}$. To obtain one fetal plasma sample, it was necessary to pool blood from eight to 10 fetuses.

\section{Preparation of tissue samples}

Adrenal glands and kidneys of fetuses and pregnant females were rapidly dissected and defatted. Adrenals from mothers were decapsuled in order to separate the capsule with zona glomerulosa from the inner tissue. All the tissues were frozen in liquid nitrogen and stored at $-80^{\circ} \mathrm{C}$. For each experiment, six to eight maternal adrenals, four maternal kidneys, 180-200 fetal adrenals and 40-50 fetal kidneys were pooled to prepare tissue samples for one binding assay.

Fetal adrenals and kidneys with medulla and maternal capsules with zona glomerulosa were ground with a Teflon homogenizer in Tris- $\mathrm{HCl}$ buffer ( $50 \mathrm{mmol} / \mathrm{l}, \mathrm{pH} 7.4$ ) containing $\mathrm{MnCl}_{2}(5 \mathrm{mmol} / \mathrm{l}), \mathrm{NaCl}$ $(120 \mathrm{mmol} / \mathrm{l})$, aprotinin $(1 \mu \mathrm{mol} / \mathrm{l})$ and bacitracin $(0.1 \%)$. Homogenates were centrifuged at $1000 \boldsymbol{g}$ for $20 \mathrm{~min}$ at $4^{\circ} \mathrm{C}$ and the supernatants were centrifuged at $20000 \mathrm{~g}$ for $30 \mathrm{~min}$ at $4^{\circ} \mathrm{C}$. The pellets containing the membranes were rinsed with Tris-HCl buffer, centrifuged again at $20000 \mathrm{~g}$ for $30 \mathrm{~min}$ at $4{ }^{\circ} \mathrm{C}$ and then diluted with Tris-HCl buffer. An aliquot was taken for protein determination and the remainder frozen in liquid nitrogen and stored at $-80^{\circ} \mathrm{C}$ until required for the binding assay. Maternal glomeruli were prepared according to the technique previously described by Sraer et al. (18). The kidneys excised from the renal capsule were cut longitudinally in order to remove the inner tissue. The minced cortical tissue was passed successively through a $106 \mu \mathrm{m}$ metal sieve, which excluded the tubules and blood vessels, and a $53 \mu \mathrm{m}$ metal sieve, which retained the glomeruli. The glomerular suspensions were rinsed three times with ice-cold
Tris-HCl buffer and centrifuged at $1000 \mathrm{~g}$ for $5 \mathrm{~min}$ at $4^{\circ} \mathrm{C}$ and then diluted with Tris- $\mathrm{HCl}$ buffer. The purity of the preparation was verified by light microscopy and tubular fragments were always less than $2 \%$ of the total number of glomeruli. An aliquot was taken for protein determination and the remainder frozen in liquid nitrogen and stored at $-80^{\circ} \mathrm{C}$ until required for binding.

\section{Binding assay}

The fetal and maternal membrane preparations at concentrations of $100 \mu \mathrm{g} /$ tube were incubated in a final volume of $250 \mu \mathrm{l}$ Tris- $\mathrm{HCl}$ buffer containing $0.5 \%$ bovine serum albumin (BSA), $25 \mathrm{pmol} / \mathrm{l}{ }^{125} \mathrm{I}-$ $\mathrm{rANP}_{(1-28)}$ (Amersham International, Amersham, Bucks, UK) and unlabelled $\operatorname{rANP}_{(1-28)}$ (Peninsula Laboratories, Belmont, CA, USA) ranging from $10^{-11}$ to $10^{-8} \mathrm{~mol} / \mathrm{l}$, for the determination of the total population of ANP receptors. The density of ANPB receptors was assessed with $\operatorname{rANP}(1-28)$ in the presence of an excess of $\mathrm{cANP}_{(4-23)}(0.1 \mu \mathrm{mol} / \mathrm{l})$ (Peninsula), a truncated ANP peptide which binds selectively to ANPC receptors. The density of ANPc receptors was obtained by subtracting the number of ANPB receptors from the total receptor population. Binding studies were performed in duplicate at room temperature for $90 \mathrm{~min}$. At the end of incubation, free ${ }^{125} \mathrm{I}_{-} \mathrm{rANP}(1-28)$ was separated from that bound to membranes, by filtration through $0.1 \%$ polyethylenimine-treated Whatman GF/ C filters (Prolabo, Marcq-en-Barœul, France), washed with $0.9 \% \mathrm{NaCl}$ and counted in an LKB gammacounter. Non-specific binding was measured in the presence of an excess of $\mathrm{rANP}_{(1-28)}(0.1 \mu \mathrm{mol} / \mathrm{l})$ and $\operatorname{cANP}_{(4-23)}(0.1 \mu \mathrm{mol} / \mathrm{l})$. Specific binding was determined by subtracting non-specific binding from total binding.

\section{Analytical methods}

Plasma rANP concentrations were measured by RIA according to the method described by Deloof \& Chatelain (9). Briefly, rANP was extracted from plasma samples with $\mathrm{C}_{18}$ Sep-Pak cartridges (Waters, St-Quentin en Yvelines, France) with acetonitrile and trifluoroacetic acid in distilled water $(60: 1: 39 \mathrm{vol})$. The evaporated eluates were incubated overnight at room temperature with rANP antibody (Bioproducts, Nanterre, France) and ${ }^{125} \mathrm{I}_{-} \mathrm{rANP}_{(1-28)}$ (Amersham). Free and bound fractions were separated by the double antibody method. Recovery of ${ }^{125} \mathrm{I}_{-} \mathrm{rANP}_{(1-28)}$ from plasma was $81.00 \pm 1.74 \%(n=10)$. The intra-assay coefficient of variation was $\pm 5.95 \% \quad(n=6)$ and the interassay coefficient of variation was $\pm 12.39 \%(n=4)$. Immunoreactive $\mathrm{rANP}$ concentrations were expressed as pmol/l.

Plasma aldosterone concentrations were measured by RIA. Details have been described previously (19). Briefly, aldosterone extracted from plasma samples with ethyl acetate after delipidation with iso-octane was incubated overnight at $4{ }^{\circ} \mathrm{C}$ with aldosterone antibody 
(Bioproducts) and 1,2,6,7 $\left[{ }^{3} \mathrm{H}\right]$ aldosterone (Amersham). Free and bound fractions were separated with a dextrancoated charcoal mixture. Recovery of labelled aldosterone from plasma was more than 95\% $(n=11)$. Intra- and interassay coefficients of variation were respectively \pm $5.06 \% \quad(n=11)$ and $\pm 10.26 \% \quad(n=7)$. Aldosterone concentrations were expressed as nmol/l.

Haematocrit was determined by the microcapillary technique (Clay-Adams microhaematrocrit). Protein content was determined by the method of Lowry et al. (20) using BSA as standard. Plasma osmolality was measured by depression of freezing-point (Rœbling osmometer).

\section{Statistical analysis}

The results are presented as means \pm S.E.M. Significance of differences between mean values was estimated by Student's $t$-test. The binding results were analysed by the EBDA/LIGAND program to determine the affinity $\left(K_{\mathrm{d}}\right)$ and density $\left(B_{\max }\right)$ of ANP receptors $(21)$.

\section{Results}

\section{Main effects of dehydration in maternal and fetal rats in late gestation}

In response to maternal dehydration, both maternal and fetal body weights decreased significantly, and plasma osmolality and haematocrit increased significantly $(P<0.001$; Table 1). After 3 days of water deprivation, maternal and fetal plasma ANP concentrations decreased $(P<0.001$ and $P<0.05$ respectively; Table 1$)$ and plasma aldosterone concentrations increased significantly $(P<$ 0.01 and $P<0.001$ respectively; Table 1 ). In control fetal rats, plasma ANP concentrations were 18 times higher than those in control pregnant rats $(P<0.001$; Table 1$)$.

\section{Effects of water deprivation on density $\left(B_{\max }\right)$ and affinity $\left(K_{d}\right)$ of $A N P$ receptor subtypes in kidneys and adrenal glands of maternal and fetal rats in late gestation}

Analysis of competition curves obtained from maternal rats revealed that water deprivation significantly increased the density of total ANP receptors in isolated renal glomeruli $(P<0.01$; Fig. 1a) and adrenal glomerulosa membranes $(P<0.05$; Fig. 1b). Quantification of the ANPB and ANPc receptors showed that dehydration significantly increased the ANPc receptor population in isolated renal glomeruli $(P<0.01$; Fig. 1a) and adrenal zona glomerulosa membranes $(P<0.001$; Fig. 1b). The density of $\mathrm{ANPB}$ receptors in renal glomeruli and adrenal zona glomerulosa membranes was unchanged $(P>0.05$; Fig. 1a,b).

No significant difference in the affinity of total ANP and ANPB receptors was observed in renal glomeruli and adrenal glomerulosa membranes when dehydrated maternal rats were compared with controls $(P>0.05$; Fig. 2a,b). Maternal dehydration did not significantly alter the density and the affinity of total ANP, ANPB and ANPC receptors in the adrenal glands and the kidneys of the fetal rat $(P>0.05$; Fig. 3a,b, Fig. 4a,b).

In control fetal kidneys, the densities of the different ANP receptors were five to six times lower than those in control maternal glomeruli $(P<0.001$; Figs 1,3$)$ and the $K_{\mathrm{d}}$ value of total ANP receptors was nearly 2.5 times higher than that of control maternal glomeruli $(P<0.05$; Figs 2a, 4a). In control fetal kidneys and adrenal glands, the $K_{\mathrm{d}}$ values of ANPB receptors were not very different from those observed in control maternal glomeruli and adrenal zona glomerulosa $(P>0.05$; Figs 2a,b, 4a,b).

Table 1 Effect of water deprivation (3 days) on maternal and fetal body weights, plasma osmolality, haematocrit, and plasma concentrations of ANP and aldosterone in late gestation. Values are means \pm S.E.M.; numbers of experiments in parentheses.

\begin{tabular}{|c|c|c|c|c|}
\hline & \multicolumn{2}{|c|}{ Maternal rats } & \multicolumn{2}{|c|}{ Fetal rats } \\
\hline & Control & Dehydration & Control & Dehydration \\
\hline $\begin{array}{l}\text { Body weight } \\
\text { (g) }\end{array}$ & $\begin{array}{c}341 \pm 6 \\
(8)\end{array}$ & $\begin{array}{c}284 \pm 7^{* * *} \\
(8)\end{array}$ & $\begin{array}{l}5 \pm 0.07 \\
(20)\end{array}$ & $\begin{array}{c}4 \pm 0.07^{* * *} \\
(19)\end{array}$ \\
\hline $\begin{array}{l}\text { Osmolality } \\
\quad\left(\mathrm{mosm} / \mathrm{kg} \mathrm{H} \mathrm{H}_{2} \mathrm{O}\right)\end{array}$ & $\begin{array}{c}282 \pm 0.7 \\
(6)\end{array}$ & $\begin{array}{c}299 \pm 1.9^{* * *} \\
(6)\end{array}$ & $\begin{array}{l}279 \pm 1.0 \\
\quad(14)\end{array}$ & $\begin{array}{c}299 \pm 1.0^{\star * *} \\
(14)\end{array}$ \\
\hline $\begin{array}{l}\text { Haemotocrit } \\
\quad(\%)\end{array}$ & $\begin{array}{l}35 \pm 0.8 \\
(8)\end{array}$ & $\begin{array}{l}46 \pm 0.9^{\star * *} \\
(8)\end{array}$ & $\begin{array}{l}31 \pm 0.6 \\
(9)\end{array}$ & $\begin{array}{c}36 \pm 1.0^{* * *} \\
(9)\end{array}$ \\
\hline $\begin{array}{l}\text { Plasma ANP } \\
\quad(\mathrm{pmol} / \mathrm{l})\end{array}$ & $\begin{array}{c}49 \pm 2 \\
(10)\end{array}$ & $\begin{array}{c}29 \pm 3^{\star \star \star} \\
(7)\end{array}$ & $\begin{array}{c}878 \pm 168 \\
(16)\end{array}$ & $297 \pm 64^{*}$ \\
\hline $\begin{array}{l}\text { Plasma aldosterone } \\
(\mathrm{nmol} / \mathrm{l})\end{array}$ & $\begin{array}{l}4 \pm 0.5 \\
(9)\end{array}$ & $\begin{array}{c}12 \pm 1.9^{* *} \\
(9)\end{array}$ & $\begin{array}{l}2.8 \pm 0.2 \\
(14)\end{array}$ & $\begin{array}{c}5.6 \pm 0.7^{* \star *} \\
(14)\end{array}$ \\
\hline
\end{tabular}

${ }^{*} P<0.05,{ }^{* *} P<0.01,{ }^{* * *} P<0.001$, compared with control values. 
Figure 1 Effect of water deprivation (3 days) on the density (Bmax) of total ANP, ANPB and $A N P c$ receptors in (a) isolated renal glomeruli and (b) adrenal zona glomerulosa membranes from control (open bars) and dehydrated (solid bars) maternal rats. Inserts represent one example of Scatchard transformation of binding data: bound/free $(B / F)$ versus bound ANP (fmol/mg protein) in (a) isolated glomeruli and (b) adrenal zona glomerulosa membranes. $\bigcirc$, -, Curves of total ANP receptors in maternal control and dehydrated tissues respectively; $\square$, $\mathbf{\square}$, curves of ANPB receptors in maternal control and dehydrated tissues respectively. Results are means \pm S.E.M.; the numbers of experiments are given in parentheses under the columns. ${ }^{*} P<0.05,{ }^{* \star} P<0.01$,

${ }^{* * \star} P<0.001$, compared with control.

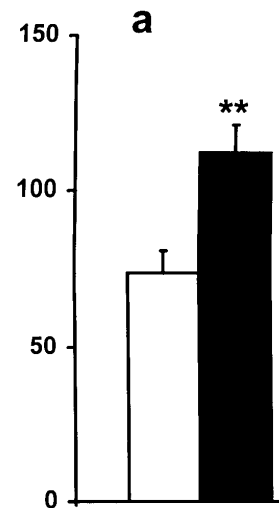

(6) (6)

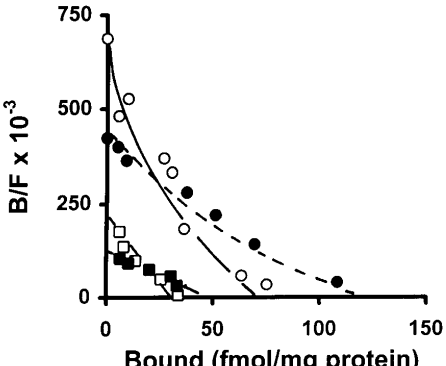

**

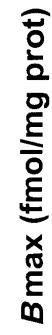

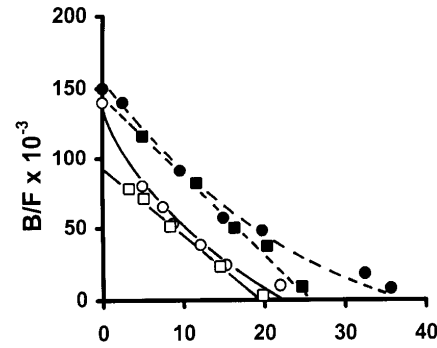

b

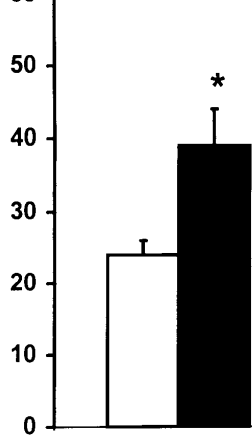

(6) (6)

(6) (6)

(6) (6)

Total ANP receptors

ANPc receptors

\section{Discussion}

In our present study, maternal water deprivation for 3 days led to a parallel decrease in both maternal and fetal body weights, and an increase in plasma osmolality and haematocrit. Several previous reports showed that water deprivation led to a weight loss that increased with the duration of dehydration in the $\operatorname{dog}(22)$ and the adult rat $(13,14,16,23,24)$, and an increase in plasma osmolality and haematocrit in the dog (22), the adult rat $(13,14,16,23,24)$, the child and the human adult $(25,26)$. In the pregnant ewe, water deprivation results in a significant increase in both maternal and

fetal plasma osmolality (27-29). However, whereas the haematocrit remains unchanged in the dehydrated ewe, it increases significantly in the ovine fetus $(27,28)$. In the dehydrated pregnant ewe, the decrease in the ruminal volume could explain the absence of a significant change of haematocrit and delay the effects of dehydration on plasma volume $(27,28)$.

Previous studies demonstrated the existence of at least two distinct types of ANP-binding sites in renal glomeruli and adrenal glomerulosa cells $(30,31)$. One is the biological receptor coupled with guanylate cyclase (ANPB receptor), which is more abundant in the adrenal zona glomerulosa cells than in renal glomeruli; the 


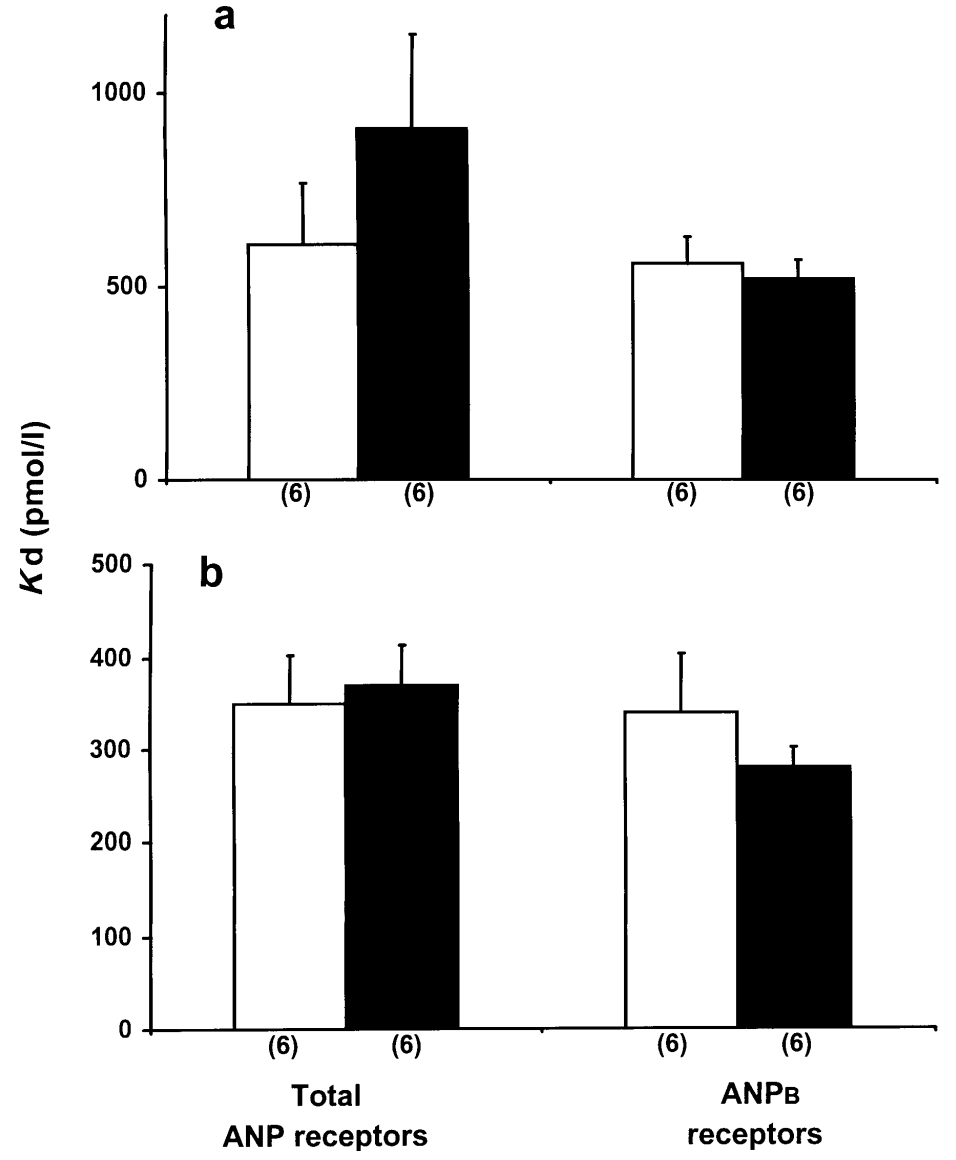

Figure 2 Effect of water deprivation ( 3 days) on the affinity $(K d)$ of total ANP and ANPB receptors in (a) isolated renal glomeruli and (b) adrenal zona glomerulosa membranes from control (open bars) and dehydrated (solid bars) maternal rats. Values are means \pm S.E.M.; the numbers of experiments are given in parentheses under the columns. other, not coupled with guanylate cyclase, is the clearance receptor (ANPC receptor), which is more abundant in renal glomeruli than in adrenal zona glomerulosa cells and can remove ANP from blood circulation (32). Both types of ANP receptor are also present in the kidneys and the adrenal glands of the fetal rat at term, in proportions similar to those observed in the adult rat (33). In the control fetal kidney, the weak density of ANPC receptors compared with that of control maternal glomeruli might contribute to the increase in fetal plasma ANP concentrations, which are greater than those of pregnant rats. Indeed, the ANPc receptors are responsible for the degradation of plasma ANP, and, when they are blocked with $\mathrm{cANP}_{(4-23)}$, the plasma ANP concentrations are much greater (34). In contrast, in the control fetal kidney, the high concentrations of fetal plasma ANP could explain the lower affinity of total ANP receptors. Indeed, these ANP receptors are probably occupied by large amounts of fetal plasma ANP and, in those conditions, the endogenous peptide still present in membrane preparations could compete with the radioligand, thus increasing the apparent $K_{\mathrm{d}}$. Unfortunately, we have not determined the $K_{d}$ values of ANPc receptors in fetal and maternal kidneys, but ANPC receptors may mainly be occupied by endogenous fetal ANP, as the $K_{\mathrm{d}}$ values of $\mathrm{ANPB}$ receptors are not significantly different in kidneys and adrenal glands of control fetal rats and those of control maternal rats.

Our results show that maternal water deprivation significantly increases the total population of ANP receptors in isolated renal glomeruli and adrenal zona glomerulosa membrane suspensions of the pregnant rat. Our results are in agreement with those of different investigators who demonstrated that water deprivation significantly increased the total number of ANP receptors in renal glomeruli of the adult rat $(13-15,17)$ and the pregnant ewe (29) and in the adrenal zona glomerulosa cells of the adult rat (17). The use of the truncated ANP peptide $\left(\mathrm{cANP}_{4-23}\right)$ allowed us to demonstrate that the population of ANPC receptors increases in the renal glomeruli of the pregnant rat, whereas the ANPB receptor density remains unchanged. These results are in agreement with those of Kollenda et al. (15), who demonstrated that water deprivation increased the population of ANPC receptors, without alteration of the ANPB receptor density, in renal glomeruli of the adult rat. Water deprivation also increases the population of ANPC receptors without modifying the density of ANPB receptors in the adrenal zona glomerulosa of the pregnant rat. This increase in ANPc receptor density in the adrenal glands and the kidneys of the pregnant rat confirms that observed in the renal glomeruli of the 
Figure 3 Effect of maternal dehydration on the density (Bmax) of total ANP, ANPB and $A N P c$ receptors in (a) renal and (b) adrenal membranes from control (open bars) and dehydrated (solid bars) fetal rats. Inserts represent one example of Scatchard transformation of binding data: bound/free (B/F) versus bound ANP (fmol/mg protein) in (a) Curves of total ANP receptors in fetal control and dehydrated tissues respectively; $\square$, curves of ANPB receptors in fetal control and dehydrated tissues respectively. Results are means \pm S.E.M.; the numbers of experiments are given in parentheses under the columns. renal and (b) adrenal membranes. $O$,

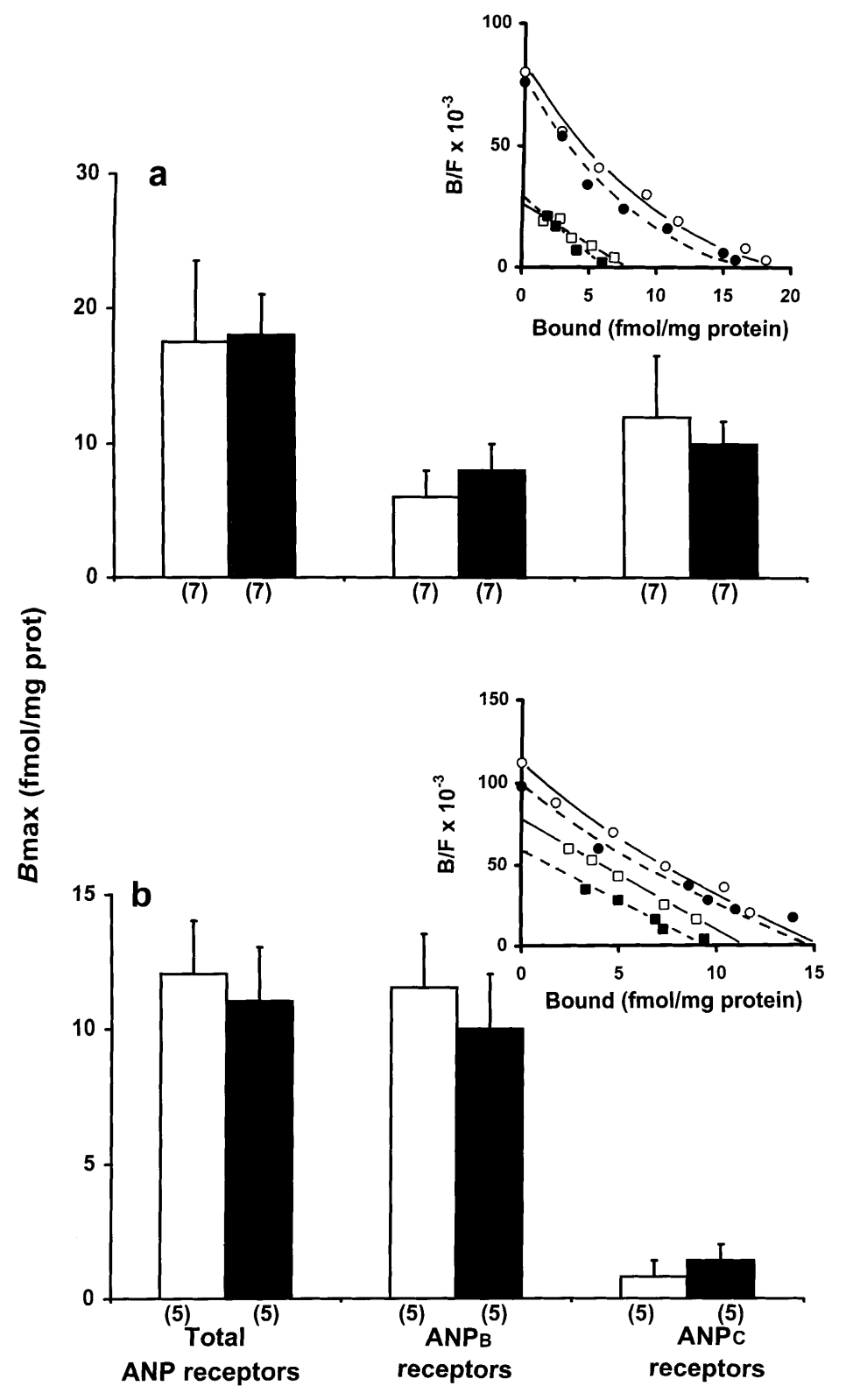

adult rat after dehydration. In fetal kidneys and adrenal glands, the densities of total ANP, ANPB and ANPC receptors remain unchanged in response to maternal water deprivation, as, in the ovine fetal renal glomeruli, the density of total ANP receptors was not affected by maternal dehydration (29).

Our results show that water deprivation of pregnant rats is associated with a significant decrease in immunoreactive ANP levels both in maternal and fetal plasmas. This result is in agreement with those of several investigators who showed that dehydration significantly decreased the release of ANP in the adult rat $(12-15,23,35)$, the pregnant ewe $(29,36)$, the child and the human adult $(25,26)$. In our dehyrated pregnant rats, the decrease in both maternal and fetal blood volumes estimated by the percentage of change in haematocrit could lead to a decrease in the release of ANP from cardiac tissue. Indeed, several studies have shown that the blood volume expansion induced by intravenous injection of saline or blood transfusion released ANP into the circulation by increasing atrial distension, in the adult rat $(37,38)$, sheep (39), fetal rats (9) and human fetuses (40). In contrast, in the adult rat, a hemorrhage, which reduces the intravascular volume and blood pressure, decreases the secretion of ANP in the circulation (24).

ANP is cleared from the circulation by two major pathways, including binding to specific ANPc receptors 


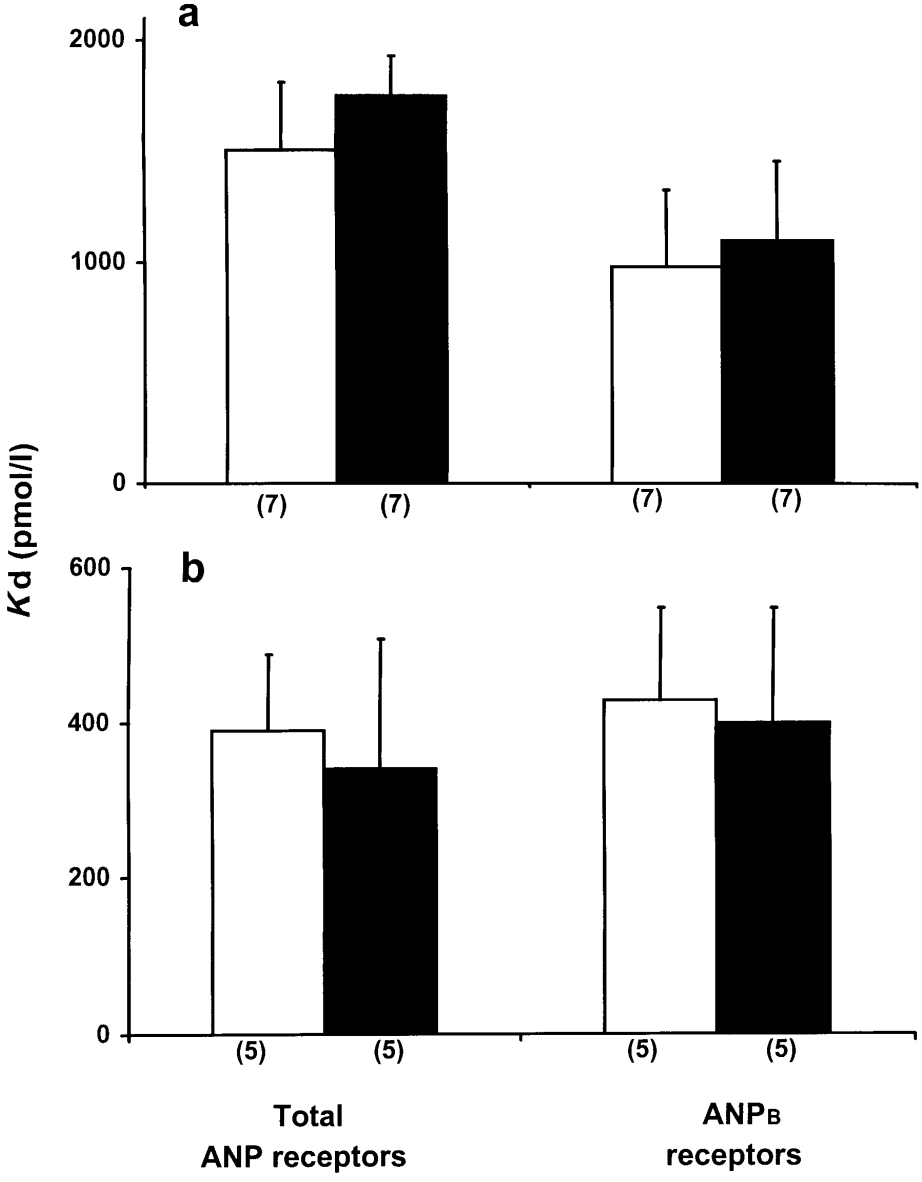

Figure 4 Effect of maternal dehydration on the affinity $(K d)$ of total ANP and ANPB receptors in (a) renal and (b) adrenal membranes from control (open bars) and dehydrated (solid bars) fetal rats. Values are means \pm S.E.M.; the numbers of experiments are given in parentheses under the columns. and enzymatic degradation of ANP by neutral endopeptidase. In our dehydrated pregnant rats, up-regulation of the ANPC receptors mainly decreases circulating ANP in association with neutral endopeptidase activity, as these two clearance pathways are additive (41). In the dehydrated fetuses, the decrease in plasma ANP concentrations is not due to up-regulation of the ANPC receptors, and in those conditions we must consider other mechanisms to explain the fetal decrease in circulating ANP. First, we have previously demonstrated that ANP does not cross the placenta in the rat (10), and the decrease in plasma ANP concentrations in dehydrated fetuses cannot be mediated through the ANPC receptor system of the mother. Another explanation for the decrease in fetal plasma ANP concentration is the presence of the placenta, which is considered to be an important site of ANP metabolism. Indeed, autoradiographic studies in the rat have shown that the placenta contains ANP receptors in abundance, located over the labyrinthine region, the decidual gland and the visceral yolk sac (42). Those placental receptors could be ANPC receptors able to clear ANP from fetal and maternal blood $(43,44)$. Alternatively, the neutral endopeptidase that is abundant in the lung, kidney and placenta of the fetal rat in late gestation is able to cleave
ANP (45). These two clearance pathways could decrease ANP concentrations in the circulation of dehydrated fetuses, but complementary studies are necessary in order to determine if dehydration is able to up-regulate placental ANPC receptors and increase the enzymatic activity of neutral endopeptidase.

An inverse relationship between the plasma ANP concentration and the density of ANP receptors has previously been reported in the adult rat (13-15) and the pregnant ewe (29). Thus water deprivation, which depresses plasma ANP concentrations in both maternal and fetal rats, increases the number of ANP receptors in kidneys and adrenal glands of pregnant rats, but not of fetal rats. This result seems surprising, because all the fetal changes observed after maternal dehydration are similar to those of the maternal rat. However, in the fetal rat at term, the adrenal gland and the kidney are not completely mature $(46,47)$ and, even if the different ANP receptor subtypes are present in those organs (33) and biologically active in the adrenal gland (19), regulation of the ANP receptors may begin after birth.

In response to maternal dehydration, plasma aldosterone concentration increases in both maternal and fetal rats. This significant increase is probably related to the decrease in ANP secretion and an increase in renin 
and angiotensin II secretion. Indeed, it is well known that ANP is involved in the inhibition of the synthesis and secretion of aldosterone by adrenal glomerulosa cells in the calf $(48)$ and the adult rat $(5,49)$. In the fetal rat, our previous in vivo and in vitro experiments demonstrated the role of ANP in the inhibition of aldosterone secretion (19). Moreover, adult rats dehydrated for $48 \mathrm{~h}$ had significantly increased renin and angiotensin II concentrations compared with control rats (50). A recent study has demonstrated that, in the adult rat, water deprivation stimulates the secretion of renin via the activation of hypothalamic histaminergic neurones (51). Indeed, dehydration stimulates the enzyme of histamine synthesis in the posterior hypothalamus (52), with the result that release of renin is stimulated (53). Unfortunately, we do not know if this histaminergic-renin system is mature in the fetal rat and can respond to maternal dehydration in order to increase aldosterone secretion.

In conclusion, our results show that, after 3-day water deprivation, the pregnant rat up-regulates its ANP receptors in adrenal glands and kidneys in response to a decrease in plasma ANP concentrations. In contrast, the fetal rat does not seem to be able to upregulate its own ANP receptors in its kidneys and adrenal glands, in spite of a decrease in plasma ANP concentrations. The inverse relationship between plasma ANP concentrations and the number of ANP receptors is observed only in the maternal rat, and not in the fetal rat.

\section{Acknowledgements}

This study was supported partly by a grant of the Conseil Régional du Nord-Pas de Calais.

\section{References}

1 Barron WM. Volume homeostasis during pregnancy in the rat. American Journal of Kidney Disease 1987 9 296-302.

2 Ballermann BJ \& Brenner BM. Biologically active atrial peptides. Journal of Clinical Investigation 198576 2041-2048.

3 Ledsome JR, Wilson N, Courneya CA \& Rankin AJ. Release of atrial natriuretic peptide by atrial distension. Canadian Journal of Physiology and Pharmacology 198563 739-742.

4 Maack T, Atlas SA, Camargo MJ \& Cogan MG. Renal hemodynamic and natriuretic effects of atrial natriuretic factor. Federation Proceedings $1986452128-2132$.

5 Schiebinger RJ, Kem DC \& Brown RD. Effect of atrial natriuretic peptide on ACTH, dibutyryl cAMP, angiotensin II and potassiumstimulated aldosterone secretion by rat adrenal glomerulosa cells. Life Sciences 198842 919-926.

6 Obana K, Naruse M, Naruse K, Sukurai H, Demura H, Inagami T et al. Synthetic rat natriuretic factor inhibits in vitro and in vivo renin secretion in rat. Endocrinology $19851171282-1284$.

7 Obana K, Naruse M, Inagami T, Brown AB, Naruse K, Kurimoto F et al. Atrial natriuretic factor inhibits vasopressin secretion from rat posterior pituitary. Biochemical and Biophysical Research Communications 1985132 1088-1094.

8 Chai SY, Sexton PM, Allen AM, Figdor R \& Mendelsohn FAO. In vitro autoradiographic localization of ANP receptors in rat kidney and adrenal gland. American Journal of Physiology 1986250 F753-F757.

9 Deloof S \& Chatelain A. Effect of blood volume expansion on basal plasma atrial natriuretic factor and adrenocorticotropic hormone secretions in the fetal rat at term. Biology of the Neonate 199465 390-395.

10 Deloof S, Van Camp G \& Chatelain A. Absence of transplacental transfer of atrial natriuretic peptide in the rat: direct experimental evidence. Medical Science Research 199523 347-349.

11 Scott JN \& Jennes LH. Ontogeny of atrial natriuretic peptide receptors in fetal rat kidney and adrenal gland. Histochemistry $198991395-400$.

12 Takayanagi R, Tanaka I, Maki M \& Inagami T. Effects of changes in water-sodium balance on levels of atrial natriuretic factor messenger RNA and peptide in rats. Life Sciences $1985361843-$ 1848.

13 Gauquelin G, Thibault G, Cantin M, Schiffrin EL \& Garcia R. Glomerular atrial natriuretic factor receptors during rehydration: plasma $\mathrm{NH}_{2}$ - and $\mathrm{COOH}$-terminal levels. American Journal of Physiology 1988255 F621-F625.

14 Gauquelin G, Garcia R, Carrier F, Cantin M, Gutkowska J, Thibault $\mathrm{G}$ et al. Glomerular ANF receptor regulation during changes in sodium and water metabolism. American Journal of Physiology 1988254 F51-F55.

15 Kollenda MC, Vollmar AM, McEnroe GA \& Gerbes AL. Dehydration increases the density of $\mathrm{c}$ receptors for ANF on rat glomerular membranes. American Journal of Physiology 1988258 R1084R1088.

16 Makino Y, Minamino N, Kakishita E, Kangawa K \& Matsuo H. Natriuretic peptides in water-deprived and in salt-loaded rats. Peptides 199617 1031-1039.

17 Lynch DR, Braas KM \& Snyder SH. Atrial natriuretic factor receptors in rat kidney, adrenal gland, and brain: autoradiographic localization and fluid balance dependent changes. Proceedings of the National Academy of Sciences of the USA 1986 83 3357-3361.

18 Sraer J, Sraer JD, Chansel D, Russo-Marie F, Kouznetzova B \& Ardaillou R. Prostaglandin synthesis by isolated rat renal glomeruli. Molecular and Cellular Endocrinology 197916 2937.

19 Deloof S, Lepretre A, Montel V \& Chatelain A. Effect of rat atrial natriuretic factor on in vivo and in vitro aldosterone and corticosterone secretions in the rat during the perinatal period. Biology of the Neonate 199262 145-154.

20 Lowry OH, Rosebrough NJ, Farr AL \& Randall RJ. Protein measurement with folin phenol reagent. Journal of Biological Chemistry 1951193 265-273.

21 Munson PJ \& Rodbard D. Ligand: a versatile computerized approach for characterization of ligand-binding systems. Analytical Biochemistry 1980107 220-239.

22 Zucker A, Gleason D \& Schneider EG. Renal and endocrine response to water deprivation in dog. American Journal of Physiology 1982242 R296-R302.

23 Januszewicz P, Thibault G, Gutkowska J, Garcia R, Mercure C, Jolicoeur F et al. Atrial natriuretic factor and vasopressin during dehydration and rehydration in rats. American Journal of Physiology 1986251 E497-E501.

24 Zongazo MA, Carayon A, Masson F, Isnard R, Eurin J, Maistre G et al. Atrial natriuretic peptide during water deprivation or hemorrhage in rats. Relationship with arginine vasopressin and osmolarity. Journal of Physiology 199286 167-175.

25 Al-Ramadani RAR. Effects of water and salt deprivation, and water and salt intake, on plasma atrial natriuretic peptide. Medical Science Research 199321 353-355.

26 Al-Ramadani RAR, Al-Gailani BT \& Murad MM. Plasma concentrations of atrial natriuretic peptide in dehydrated patients. Medical Science Research 199321 163-171.

27 Ross MG, Sherman DJ, Ervin MG, Castro R \& Humme J. Maternal dehydration-rehydration: fetal plasma and urinary responses. American Journal of Physiology 1988255 E674-E679. 
28 Schreyer P, Sherman DJ, Ervin MG, Day L \& Ross MG. Materna dehydration: impact on ovine amniotic fluid volume and composition. Journal of Developmental Physiology $199013283-$ 287.

29 Fujino Y, Ross MG, Ervin MG, Castro R, Leake RD \& Fisher DA. Ovine maternal and fetal glomerular atrial natriuretic factor receptors: response to dehydration. Biology of the Neonate 199262 120-126.

30 Maack T, Suzuki M, Almeida FA, Nussenzveig D, Scarborough RM, McEnroe GA et al. Physiological role of silent receptors of atrial natriuretic factor. Science 1987238 675-678.

31 Mulay S, Omer S, Vaillancourt P, D’Sylva S, Singh A \& Varma DR. Hormonal regulation of atrial natriuretic factor receptors and effects on adrenal glomerulosa cells of female rats. Life Sciences 199455 169-176.

32 Maack T. Receptors of atrial natriuretic factor. Annual Review of Physiology $19925911-27$.

33 Deloof S, De Seze C \& Chatelain A. Identification of two distinct classes of binding sites for atrial natriuretic peptide in the kidney and adrenal gland of the fetal rat at term. Medical Science Research 199624 563-565.

34 Chevalier RL, Muchant DG, Thornhill BA, Belmonte DC, Pence RA \& Baertschi AJ. Regulation of the renal response to atria natriuretic peptide by sodium intake in preweaned rats. Pediatric Research 199640 294-299.

35 Schwartz D, Katsube NC \& Needleman P. Atriopeptin release in conditions of altered salt and water balance in the rat. Biochemical and Biophysical Research Communications 1986137 922-928.

36 Dodd A, Chan K, Kullama LK, Ervin MG \& Ross MG. Dehydration increases the renal response to atrial natriuretic peptide in fetal sheep. American Journal of Obstetrics and Gynecology 1992167 1710-1716.

37 Petterson A, Hedner J, Ricksten SE, Towle AC \& Hedner T. Acute volume expansion as a physiological stimulus for the release of atrial natriuretic peptides in the rat. Life Sciences $1986381127-$ 1133.

38 Khraibi AA, Granger JP, Burnett JC, Walker KR \& Knox PG. Role of atrial natriuretic factor in the natriuresis of acute volume expansion. American Journal of Physiology 1987252 R921R924.

39 Bennett TL \& Rose JC. Atrial natriuretic factor responses to volume expansion in pregnant and non-pregnant sheep. American Journal of Obstetrics and Gynecology $19891651627-$ 1634.

40 Panos MZ, Nicolaides KH, Anderson JV, Economides DL, Rees L \& Williams R. Plasma atrial natriuretic peptide in human fetus: response to intravascular blood transfusion. American Journal of Obstetrics and Gynecology 1989161 357-361.
41 Okolicany J, McEnroe GA, Koh GY, Lewicki JA \& Maack T. Clearance receptor and neutral endopeptidase-mediated metabolism of atrial natriuretic factor. American Journal of Physiology 1992263 F546-F553.

42 Scott JN. Atrial natriuretic peptide binding in rat placenta, yolk sac, decidua, and maternal placental vessels. Cell and Tissue Research 1993272 391-394.

43 Alexander DP, Anwar A, Britton HG, Foster CL, Maplesden R, Pain SJ et al. Atrial natriuretic factor (ANF) in the sheep fetus. Journal of Physiology 1989413 3P.

44 McQueen J, Kingdom JCP, Whittle MJ \& Connell JMC. Characterization of atrial natriuretic peptide receptors in human fetoplacental vasculature. American Journal of Physiology 1993264 H798-H804.

45 Dutriez I, Salès N, Fournié-Zaluski MC \& Roques BP. Pre- and postnatal ontogeny of neutral endopeptidase 24-11 (enkephalinase) studied by in vitro autoradiography in the rat. Experientia 199248 290-300.

46 Barnes AC. Functional differentiation of the kidney. In Intrauterine Development, pp 245-252. Ed AC Barnes. Philadelphia: Lea \& Febiger, 1968.

47 Idelman S. The structure of the mammalian cortex. In General, Comparative and Clinical Endocrinology of the Adrenal Cortex, pp 1200. Eds IC Jones \& IW Henderson. New York: Academic Press, 1978.

48 Cozza EN, Foecking MF, Del Carmen Vila M \& Gomez-Sanchez CE. Adrenal receptors for natriuretic peptides and inhibition of aldosterone secretion in calf zona glomerulosa cells in culture. Acta Endocrinologica 1993129 59-64.

49 Campbell WB, Currie MG \& Needleman P. Inhibition of aldosterone biosynthesis by atriopeptins in rat adrenal cells. Circulation Research 198557 113-118.

50 Di Nicolantonio $\mathrm{R}$ \& Mendelsohn FAO. Plasma renin and angiotensin in dehydrated and rehydrated rats. American Journal of Physiology 1986250 R898-R901.

51 Kjaer A, Knigge U, Jorgensen H \& Warberg J. Dehydration-induced renin secretion: involvement of histaminergic neurons. Neuroendocrinology 199867 325-329.

52 Kjaer A, Larsen PJ, Knigge U \& Warberg J. Dehydration stimulates hypothalamic gene expression of histamine synthesis enzyme: importance for neuroendocrine regulation of vasopressin and oxytocin secretion. Endocrinology 1995136 2189-2197.

53 Zanchetti A \& Stella A. Neural control of renin release. Clinical Science and Molecular Medicine 19752 215S-223S.

Received 10 February 1999

Accepted 26 April 1999 